[Pre-print version]

Romance Studies, 18, 2, Dec 2000. (Published by Maney.)

\title{
INSIDE THE LABYRINTH: THE THEMATICS OF SPACE IN THE FICTION OF PAOLA AT A CAPRIOLO
}

\author{
GILLIAN ANIA \\ University of Salford, U.K.
}

In Capriolo's fiction we see, above all, the centrality of place in the minds and lives of her protagonists, often linked with the idea of the labyrinth: labyrinth as endless tortuous passageways, enclosed place, puzzle, quest. The stories, built around the obsessions of their protagonists, transcend normal temporal and spatial boundaries, and reflect the labyrinth in various forms: as a physical maze; as mirror reflections, sometimes infinitely receding; as a remote, closed-off place; and as a metaphor suggesting confusion of the mind or of ideas. As well as a considerable degree of overlap within these areas, there is a pervading, underlying sense of ambiguity, and the idea of permanence and of eternal 'being'.

\begin{abstract}
Nessun prezzo è troppo alto per la verità, anche se vado sempre piú convincendomi che la salvezza stia nell'errore, che il labirinto della vita si percorra piú agevolmente con sguardo offuscato. Vedere significa vedere l'abisso, da cui non è possibile tornare poi a distogliere gli occhi. ${ }^{1}$
\end{abstract}

Paola Capriolo's use of the figure of Scarpia as emblematic spokesman for her metaphysicalliterary concerns is both interesting and revealing: a chief of police, rather than a musician, actor or artist, he frequently engages in philosophical discourse in his personal search for truth, and seems to see more clearly than any of the other main protagonists, even though he does not act on his understanding. And yet he is a double fiction, a character from an opera libretto, suggestive of an even greater detachment from 'reality'. As Capriolo has said of her work: 'La consapevolezza che il romanzo appartiene alla sfera della finzione significa quindi che la finzione diventa il luogo in cui si compie questa ricerca della verità, e c’è un rapporto che è quasi paradossale tra questi due aspetti." ${ }^{2}$ The lines from Scarpia's diary highlight and encapsulate Capriolo's central themes, not only in Vissi d'amore, but in all her novels and stories to date: we see an espousal of truth - whatever this means for the individual - which is to be sought whatever the consequences; a belief that salvation is to be found, intriguingly, in error; and a sense of life as a labyrinth, life which can be lived more easily if one cannot see the way ahead clearly, for if there is clarity of vision, one is caught up in the vortex, with no turning back. For Scarpia, 'il labirinto della vita si percorr[e] piú agevolmente con sguardo offuscato'. But what picture do we get of this experience, how can one live with 'clouded vision', and what is the 'labyrinth of life'?

A 'post-modern' writer, as Sharon Wood has stated, for her 'frame of reference from Romanticism to Modernism, ${ }^{3}$ Capriolo shares the post-modern obsession with space, outer 
and inner space(s), and its relationship with time. Her stories contain elements of the fantastic, often overturning temporal and spatial norms, although set in clearly recognizable worlds, and grounded in human experience. Other post-modern characteristics to be observed are a questioning of authorial authority, an obvious interest in the ambiguous nature of linguistic symbols, and elements of magic realism, the neo-Gothic, parody and pastiche. ${ }^{4}$ The spaces we encounter in Capriolo's fiction - prisons, hotels, and theatres, each a place of dislocation, of displacement from the 'normal' world, willed or otherwise - frequently take labyrinthine form. The idea of the labyrinth suggests primarily a physical and mental puzzle, endless pathways, an enclosed place, and the possible presence of a 'minotaur', something to be either avoided or conquered. What characteristics will Capriolo's labyrinths have? Will we find a multicursal model which, as Penelope Reed Doob states, with its interminable choices and dead ends is intended to confuse, frustrate and entrap, or a unicursal maze with a single winding path, which leads ineluctably to 'heaven, hell or knowledge'? ${ }^{5}$ The labyrinth may, as in the symbolism of the ancient Egyptians, represent the path followed by the dead in the underworld, and/or denote, as in medieval Christianity, the true way of belief (although originally a maze symbolized the path of ignorance leading away from God). It may be seen, as in Dante's Inferno, as a symbol of destructiveness, of the dark, violent depths in man, or as a symbol for time itself, with the journey to the centre symbolic of the mystic return to the womb. Labyrinth can also be quest, as in the case of the Cretan model. Furthermore, interest in a labyrinth can focus on its complex artistry and (sinister) purpose, or on the experience of the individual inside the maze, suffering 'intellectual confusions and moral delusions' ${ }^{6}$ It may be that a writer constructing labyrinths, most of which are circular and cyclic, is playing out an urge to overcome some fear (death, even) and renew life, and this seems relevant in Capriolo's fiction where we see, above everything, the importance of place in the minds and lives of her protagonists, and the pull towards a kind of monastic exclusion or oblivion.

The term labyrinthine can also apply to a text itself, resulting in some degree of frustration for readers who must grope their way through it, unguided, as in the later novels of Calvino, or those of Borges, Kafka and Robbe-Grillet. While Capriolo's novels do not have this extreme effect, there is a similar sense of disorientation, perhaps reflecting the modern sense of alienation in a fast-moving, often impersonal world. It is certainly true that Capriolo feels ill at ease in the modern world, preferring solitude and the safety of her own four walls. ${ }^{7}$ Labyrinthine texts can be 'open', in that choices have to be made and so the reader is invited to play a more active role, or they may seem 'closed' structures, with no way out. Ben Stoltzfus has posited two different kinds of artists: those who accept and portray the world as it is, and those who, like Robbe-Grillet, try to create a new world, either a world which does not exist or which is remote from the world as we know it. ${ }^{8}$ Remaining within the theme of the labyrinth, Lawrence Durrell and Giorgio Caproni provide examples of the former category, ${ }^{9}$ while Capriolo, together with Calvino and Borges, offers readers new worlds. ${ }^{10}$ Closer to Stoltzfus's second grouping, Capriolo creates both worlds which do not exist (Il doppio regno, 'La grande Eulalia') and those which are remote from our experience ('La donna di pietra', 'Il gigante', Vissi d'amore, La spettatrice, Un uomo di carattere).

As far as time and space are concerned, Capriolo's stories certainly transcend normal boundaries, as we see with the life observed through the mirrors in 'La grande Eulalia', and the structure of the hotel of Il doppio regno with its imposing entrance but elusive exit. They are built around the obsessions of their protagonists, and therefore follow the rules of this obsession, rules which do not necessarily coincide with the usual laws governing time and space, although the stories rarely unfold in surreal atmospheres. ${ }^{11}$ Within the space which the protagonists 'choose' or are drawn to - hotel, theatre, or prison - and in which they live out their various obsessions, there is, notably, a subordination of the external to the internal. As Capriolo has explained: 
Questo spazio dell'ossessione è necessariamente uno spazio chiuso e che tende a chiudersi, e nello stesso tempo è uno spazio che arriva a comprendere tutto l'orizzonte mentale del protagonista, a poco a poco assorbe tutto in sé, non c'è piú niente fuori. ${ }^{12}$

The outside, the objective condition of the tormented psyche, thus reflects the inside, the process or processes going on in the mind, and the growing exclusion from the 'real' world and the consequent identification with, and concentration on, the one closed image proceed in parallel.

What place, then, does the labyrinth have in Capriolo's work? Although there is not such a clear distinction between the forms, we may see the labyrinth reflected in the following broad categories: as a physical maze form; as mirror reflections, sometimes infinitely receding; as a remote, closed-off place; and as a metaphor suggesting, for example, confusion of the mind or of ideas. As well as a considerable degree of overlap within these areas, there is a pervading, underlying sense of ambiguity, and the idea of permanence and of eternal 'being'. Let us now turn to some of the short stories ('La grande Eulalia', 'Il gigante', 'Lettere a Luisa'), and novels (Il doppio regno, Vissi d'amore, La spettatrice), to examine the ways in which the labyrinth is represented.

\section{A Physical maze}

Right from Capriolo's first stories, we see the importance of place, that is, of buildings and 'homes', such as the van belonging to the troupe of actors in 'La grande Eulalia'. Although not a maze as such, it has a Tardis-like quality in that it is much bigger inside than it appears from the outside. ${ }^{13}$ Similarly, whilst the image of a physical labyrinth could not be classed as a feature of La spettatrice, it is not entirely absent. In order to reach the room where the theatrical costumes are kept, 'bisognava farsi strada in un labirinto di cavi e di funi', the term here serving to illustrate a tangle of ropes and cables. ${ }^{14}$ The costumes themselves are kept in a series of enormous trunks which line the walls of the room. They are arranged in alphabetical order according to the title of the play or opera, their labels indicating which, and thus the room seems like 'una disordinata biblioteca' (LS, p. 100). The link between labyrinth and library, perhaps even coincidental here, is particularly developed in Il doppio regno. ${ }^{15}$

Indeed, by far the most striking occurrence of the physical maze is in this novel. The hotel has been built according to 'criteri particolari', ${ }^{16}$ and even the manager does not possess a plan of its layout. The protagonist loses her way in the profusion of rooms and winding interlinked corridors in the hotel, and rarely ventures outside the area she knows. In order to be shown the library, Cara notes in her diary that she follows one of the waiters 'per una serie labirintica di corridoi' (DR, p. 46). With echoes of Umberto Eco, the library, with the kind of books it stores and its extensive but obscure card indexes, is also the labyrinth, the path to the unknown, but, without a key (in this case, language), it represents only the chaos of silence. Cara decides to go out of the hotel, to retrace her steps back down to the sea, but she is unable to find the exit to the maze, even with the assistance of various amenable waiters; indeed their very amenability, like the non-language of the library books, is also a part of the labyrinthine chaos. Each waiter has only a limited, partial knowledge of his sector, all the rest of the hotel is uncharted territory, and even with their combined efforts they cannot help Cara. Perhaps it would require too many specialisms concentrated in one person to fathom the meaning and direction of the total maze. Stoltzfus has commented that the labyrinths constructed by Borges, Kafka, and Joyce, as they are all places with no exit, no longer protect man, but 
present a threat. ${ }^{17}$ Where does Capriolo fit in with this? Are her labyrinths threatening? The manager, who utters rational but unhelpful statements with regard to the existence of a plan of the hotel, seems to be saying that since Cara got into the hotel, therefore she must be able to find the way out by herself. He is unable, or unwilling, to help her, and Cara is left to tread the maze alone, to work out her own 'salvation', discover her own 'truth'. Perhaps if 'la salvezza [è] nell'errore', trial and error is the key. The poem 'I limoni' from the collection 'Ossi di seppia' by Montale (a poet much admired by Capriolo), expresses a similar idea:

Vedi, in questi silenzi in cui le cose

s'abbandonano e sembrano vicine

a tradire il loro ultimo segreto,

talora ci si aspetta

di scoprire uno sbaglio di Natura,

il punto morto del mondo, l'anello che non tiene,

il filo da disbrogliare che finalmente ci metta

nel mezzo di una verità. ${ }^{18}$

Truth, then, as Scarpia posits and Cara ponders, is to be found in 'error' 19

At first Cara proceeds because she appears to be led by a sense of logic: there must be a way out. But gradually, as is not surprising for those who spend any length of time living in the dark or in semi-darkness, an ever-growing sense of unreality comes to the fore, she experiences confusion, anxiety, and frustration, and she accepts that she will not find the exit, the 'maglia rotta nella rete | che ci stringe', as Montale calls it in 'In limine', the opening poem of Ossi di seppia. ${ }^{20}$ Cara's days are all the same, with no variety, and this routine, with its cyclic patterns and rhythms, brings comfort. It also begins to bring, or replace - or even become, as in Milan Kundera's The Unbearable Lightness of Being - meaning. ${ }^{21}$ Yet at times the geometry of the hotel is subordinate to Cara's intention to get where she wants to, as she records: 'i percorsi tortuosi si facevano semplici, la complessità labirintica [...] si dissolveva davanti a me, quasi ne possedessi il filo d'Arianna' (DR, p. 95). One 'advantage' of the labyrinthine structure of the hotel is that Cara, now a habitué of the maze, can avoid the three guests (who later arrive) when it suits her: 'l'albergo è grande, e io conosco meglio di lui [Bruno] i passaggi nascosti, le svolte dei corridoi, gli angoli bui dove si può rendersi improvvisamente invisibili' (DR, pp. 99-100).

When Cara reaches her state of total identification with the hotel, she notes: 'Non esiste altro mondo che il mondo, e il mondo è un insieme di corridoi e di stanze in penombra, labirintico' (DR, p. 165). The hotel, then, is life, its corridors perhaps representing direction and choices. But here they lead only to the library, restaurant and garden: three places representative of man's order imposed on chaos, both in 'normal' life and in the hotel, although the hotel represents a state of excessive control: rigid but unintelligible bookcataloguing, homogenous and insipid food, and an over-luxuriant hot-house garden. Fulfilment, perhaps, cannot be achieved unless reason/order, and instinct/nature, achieve total harmony. As far as Cara is concerned, it imports little which way she goes, which corridor she chooses. She can see only so far ahead along the corridors (as if she were subject to a Pirandellian 'lanterninosofia', going through life with just a little light/knowledge), she knows the routine of the hotel, and she feels safe in the knowledge that she will not find the exit by mistake - a discovery which, were it possible, would provoke a trauma. Her hotel, then, with the statuesque pyramids standing tall in the corridors and Cara's own feeling of being 'buried' or abandoned there, suggests the image of an Etruscan maze, or (Egyptian) tomb. ${ }^{22}$ 


\section{Mirror Reflections}

Inside a labyrinth one's perspective can alter dramatically, the effect being a sort of optical illusion. In 'La grande Eulalia', the walls of Eulalia's room, covered with mirrors, fascinate and completely absorb the young girl: 'lo sguardo della ragazza si smarriva estasiato in quel labirinto di immagini' (GE, p. 17). What she sees 'through the looking glass', appear to be not simply flat mirror images multiplied, but three-dimensional images that have a life of their own and magnetize the onlooker. Her eyes feast on a handsome figure, 'l'uomo che vive negli specchi' (GE, p. 18), she is captivated, and her life alters dramatically.

Yet Eulalia is not the only one to be affected by the mirrors. When the narrator looks into or perhaps through - 'quelle pareti di cristallo' (GE, p. 18), she feels quite dizzy: 'il gioco infinito degli specchi mi diede un senso di vertigine’ (GE, p. 18). Mirrors, like the labyrinth, can confuse as well as attract and dazzle. Worried about her protégée's melancholy mood, the narrator hides in her room, waits, and watches. Slowly, a figure appears, walking 'per la serie infinita delle stanze' (GE, p. 21). He recedes into the distance, 's'inoltrò nell'abisso limpido del cristallo', then returns to the surface, and for the narrator, the reflection is infinitely more splendid than reality: 'Mi pareva che tutta la magnificenza della terra non fosse che l'eco sbiadita di quella che appariva là, nello specchio' (GE, p. 21). Scarpia of Vissi d'amore will develop this idea, as we shall see.

When Eulalia looks into her mirrors one day to see a beautiful maiden with her 'cavaliere' walking through 'il dedalo delle stanze' (GE, p. 23), as if there truly were a labyrinth of rooms within the mirrors, she is consumed with jealousy. The man and woman appear far off and out of focus at first, then as they approach, their contours become more clearly defined. Up to this point, there is a definite sense of division between the world inside the mirrors, and that outside. Yet from here an osmotic flow gradually seeps from the former to the latter as Eulalia seeks to emulate the movements and grace of the maiden, so, in a sense, becoming her, and the two worlds fuse.

Having become a famous actress and singer following her 'fatal attraction', Eulalia designs three splendid palaces which are built on islands linked by invisible bridges, 'ponti invisibili, di cristallo' (GE, p. 29), on the surface of the water. In a passage that captures the essence of Capriolo's writing, the narrator notes:

Quei tre splendidi edifici [...] tramandano il gusto [di Eulalia] per i giochi piú sottili tra realtà e finzione, per l'intrecciarsi infinito delle somiglianze, per l'inganno sublime degli specchi, che cattura l'occhio e lo piega alle leggi prospettiche di uno spazio immaginario. (GE, p. 29)

Like Eulalia, Paola Capriolo derives obvious satisfaction from constructing her imaginary spaces, blending reality and fiction, playing games with her readers, attracting and deceiving them, as if they were inside a labyrinth. The mirror reflects, or interprets, 'reality' and creates a selective, normally two-dimensional view of it, but the eye too interprets: it selects according to its subjectivity; it creates an illusion as does the mirror, an illusion we believe in as reality. And this is the case with Eulalia.

Since all the reception rooms at the central palace are linked by mirrors, it is almost impossible to tell the real from the reflected image, which appears to be the precise intention. 'Il centro di quel labirinto era un ampio salone ottagonale' (GE, p. 31), and as Eulalia approaches, her image is reflected and multiplied, and the guests are confused, deceived. Which is the real Eulalia? Perhaps she is trying to escape reality, like Calvino's narrator of 'In 
una rete di linee che s'intersecano', of Se una notte d'inverno un viaggiatore, where the mirror is similarly the central focus ('Eे la mia immagine che voglio moltiplicare, ma non per narcisismo o megalomania come si potrebbe troppo facilmente credere: al contrario, per nascondere, in mezzo a tanti fantasmi illusori di me stesso, il vero io che li fa muovere'). ${ }^{23}$ This multiplicity of reflected images not only echoes the (Pirandellian) theme of multiple identity (because each person's view is relative and selective), prominent particularly in $I l$ doppio regno and La spettatrice, but also reflects the structure of the text, in which readers have to find their way, attempting to determine how reliable the narrator is, and what constitutes 'reality'. Eulalia is here trapped in her labyrinth of mirrors, waiting, although eventually she will choose it permanently. As the narrator herself had recognized, what the world offers is only pale in comparison, a poor copy of the world of the mirrors.

In Vissi d'amore Scarpia reasons that, since the powers of the imagination are far stronger than reality, the theatre is a more dangerous place for a man than the brothel. In the same way, a female reflection or portrait causes a more lasting effect than the woman in flesh and blood: 'L'immagine di una cosa fa maggior danno della cosa stessa' (VA, p. 24), since the image has no physical or spatial limits. He is captivated by Cavaradossi's painting of Tosca, has it stolen, and places it in his torture chamber, ambiguously named 'Paradiso'. When he visits Tosca in her dressing room at the theatre, he notes that she glances furtively in her mirror 'come se per accertarsi che la propria immagine non fosse nel frattempo mutata' (VA, p. 67). Perhaps we need mirrors to keep some sort of a check on ourselves, on our identity, or even to create or inflate it. When Vulpius of La spettatrice observes the stage and stalls in the theatre as if for the first time, he turns off all the lights, and imagines not just one 'spettatrice', but a whole crowd, rather as if they were mirror reflections of the woman, all looking at him, 'spettatrici dai lunghi capelli scuri e dagli occhi neri puntati su di lui' (LS, p. 57). In Il doppio regno mirrors are conspicuous by their absence, and Cara is consequently unable to witness any changes in her appearance. The prisoner of 'Il gigante', however, as he tells us, in 'Lettere a Luisa' (the two stories are linked, the former being the diary of the prison governor, Eugenio, and the latter that of the prisoner, known as 'the giant'), looks into his mirror as little as possible. ${ }^{24}$ Mirrors, then, appear to be avoided (or removed), if identity, change, or the passing of time, are feared in some way.

\section{A remote closed-off place}

Labyrinths, as well as being tortuous and confusing, constructed to fascinate and amuse, also torture and confine, sometimes leading to permanent enclosure. They are often linked with an apparent lack of purpose or sense. Within the overturning of the spatial and temporal laws, mentioned above, is the dominance of the inside of buildings, whether theatre, prison, or hotel. In the same way we see the subordination of external 'reality' and the all-importance of the internal 'realities' of the protagonists.

Eulalia is restless, waiting night after night for her mirror man to materialize. When he finally does, her expectations are shattered as he is not 'l'uomo degli specchi' (GE, p. 38), that is, not the idealized image she had imposed on the real 'him'. She shuts herself away in her mirrored room, her refuge turned prison, and never re-emerges. We are not told if she enters her looking-glass world, 'il mondo magico degli specchi' (GE, p. 35), which would constitute a fantastic ending, or whether she fades away and dies, a more realistic ending. Capriolo appears to be saying, however, that 'reality' is ungraspable because between it and us is our own imaginative fancy, which is our hope, our delight, our suffering, our prison, our all. Or perhaps we always die, eventually, having lived always in the 'magical world of mirrors'. 
Eulalia's confinement in her room of mirrors is '[una] prigionia volontaria' (GE, p. 41), since she locks herself away, and yet has the freedom to leave should she wish, unlike that of the prisoner of 'Il gigante'. His prison is instead 'purpose-built', constructed in isolated, desolate terrain to cut off its inhabitants (the prisoner, especially, though also the prison governor Eugenio, and his family), yet also to protect the family from the outside world. Eugenio writes: ' $E$ forse il carcere [...] esiste soltanto per separarci dal mondo e consentire alla nostra vita di scorrere indisturbata, protetta dai drappelli di soldati che pattugliano l'edificio., ${ }^{25}$ Both the prisoner and Eugenio, however, begin to wonder whether the outside world still exists: 'C'è ancora un mondo là fuori?' (IG, pp. 67, 68, 71, 106). ${ }^{26}$ An aura of mystery surrounds the prisoner, who can only be reached after passing through twelve empty rooms, each one securely bolted. Eugenio knows almost nothing at all about him, or what his horrendous crime was, just that the prison was built for him and will be destroyed on his death. This links us not only with the tale of the Cretan labyrinth, constructed as a prison to punish a particularly monstrous sin, but also with Dante's mountain of Purgatory, to pass away on the day of judgement.

The prison building, described as 'una grande massa scura' (IG, p. 76), affects all those living in its shadow. It makes Adele, Eugenio's wife, feel cold, despite the warm summer afternoon, and it exercises 'un'impressione sinistra' on her cousin, Teresa (IG, p. 80). In Teresa's view, Adele is living in '[un] luogo di clausura' (IG, p. 80), and Eugenio himself considers his wife almost as a second prisoner. There is a clear sense of division between the private, closed-off world of the prison and the rest of humanity. Gaspare, one of the guards, is dismayed on receiving his orders to leave, and Eugenio too cannot contemplate the idea of returning to the city: ' $\mathrm{E}$ come se fossimo qui da sempre, e per sempre fossimo destinati a rimanervi' (IG, p. 86). The force of habit, repetition, and routine, bring comfort and meaning, just as Cara feels in the hotel, and indeed the guards at the remote fortress in Buzzati's Il deserto dei Tartari, and the inmates of the sanatorium in Mann's The Magic Mountain. Eugenio does recognize the hold the prison has on him:

A volte mi pare di essere sotto l'effetto di uno di quei veleni blandi ma insidiosi che s'impadroniscono a poco a poco dell'organismo, lo invadono tutto, sostituendo alla salute uno stato di ingannevole benessere, un piacere misto a repulsione, di cui non si può fare a meno. (IG, p. 86)

Inexplicable and bizarre, it is, nevertheless, too strong for him to resist.

The hotel, the space of Cara's obsession, is both her cage and the world: 'Forse l'albergo è soltanto la gabbia che mi sono fabbricata, il farsi spazio di un'ignota ossessione’. But she goes on: 'Mi pare sempre piú che il mondo intero sia un prodotto della mia malattia, di esistere io sola, frantumata in una molteplicità di maschere' (DR, p. 153). ${ }^{27}$ The self hidden behind the masks is 'una voragine che inghiotte tutto, che comprende tutto, anche l'albergo questo mio corpo immenso nel quale mi smarrisco' (DR, p. 154). Cara is seeking some sort of solid identity, having no real memories of her 'previous' life. When she finds it almost impossible to explain her reluctance to leave the hotel with the three guests, Guido comments that her position is not so unusual: 'spesso i reclusi si affezionano alla loro prigione' (DR, p. 125), as was the case in 'Il gigante'. Cara replies that it will not be long before she does not know what 'recluso' or 'prigione' even mean. Words do not, or cannot, have a fixed significance, or perhaps it is rather that language is at variance with 'reality', just as society and 'sociability', if subjective criteria, are at variance with 'reality', assumed to be objective; the same is true of the books in the hotel library, written in a totally non-referential 'language' of signs. Indeed, at the end of the novel the protagonist, who has seemingly solved the maze, decides to stay, and to become it: 'Io [...] non sono nulla, o se sono qualcosa sono l'albergo' 
(DR, p. 168). Cara, then, accepts that she is her own prison.

In La spettatrice, two places are said to be important. 'Immaginiamo una tranquilla città [...] della quale per il momento ci interessano soltanto due edifici' (LS, p. 8): the theatre and the boarding-house where the actors reside during the season. The importance of the theatre, the place where one can re-create the self in many forms, is underlined when Vulpius pictures a face-to-face meeting with 'la spettatrice', quite convinced that 'il luogo dell'incontro poteva essere soltanto uno' (LS, p. 53), and as he heads there 'quell'edificio, di solito cosí ospitale appariva caparbiamente concentrato in se stesso' (LS, p. 53). There is no change of 'season' inside the theatre, and with no clocks, thereby breaking the last link with the outside world, even time seems to stand still inside, as in the hotel of Il doppio regno. The unchanging surroundings and rhythms are all part of the attraction, for Vulpius as for Cara and Eugenio.

Vulpius feels that the theatre is his home, 'la propria dimora' (LS, p. 145), just as Cara feels with regard to her hotel. Vulpius also extends this feeling to the unknown, mysterious female spectator who has become his 'raison d'être', as perhaps, in a less dramatic way, Cara does with the waiters. The narrator of La spettatrice notes: 'Le altre spettatrici [...] erano lí come ospiti, invece la sconosciuta sembrava avere nel teatro la propria autentica dimora, tanto che gli era quasi impossibile pensarla fuori di esso' (LS, p. 45). Vulpius believes that she must come to the theatre solely for him, yet it could be that it is only his impression that she is looking at him, and that instead it is some sort of 'Mona Lisa' effect, each believing the eyes are following him or her alone. At the end of the story Vulpius takes charge by offering himself, as opposed to Cara to whom control is offered, and inside the theatre, 'soltanto lui è reale, soltanto a lui il teatro appartiene davvero quale possesso esclusivo, perché Vulpius è diventato a sua volta un possesso esclusivo del teatro' (LS, p. 151), with all the parts of the theatre linked to him, just like parts of the body. In his final recognition and acceptance of the self, Vulpius belongs to and is the theatre, as Cara belongs to and recognizes that, if she is anything, she is the hotel. They both seek something permanent, initially feared, then wholeheartedly desired, an imprisonment, or fixity, achievable only in death.

We have already referred to the effect of external factors or events on the inner self. The wave of Il doppio regno offers one example of this process. Dramatic and threatening at the beginning, it reflects the troubled state of the protagonist, not only at this moment, but for a longer 'present'. The memory of the wave (and its possible resurgence) still causes Cara anxiety, even when she is inside the hotel. The enclosed space, then, while offering physical refuge, does not protect from mental torment. Scarpia's offices provide a second example. They are his space, his own private space in which he never receives anyone and he takes obvious delight in the fact. Tosca, however, crosses his threshold, both literally and metaphorically, and he cannot but be affected: 'Ora invece non potrò piú attraversare l'anticamera senza pensare alla repentina, incredibile invasione che Tosca ha osato compiere' (VA, p. 46). She, despite his rational resolve, his attempt to remain detached, and above her, has become imprinted on his mind, has invaded his physical space and mental state, and has brought about his transformation. His safe house is no protection against feelings, the 'assalti di un’altra potenza [...] cui [...] davo nei miei pensieri il nome di Maria Trionfatrice’ (VA, p. 86).

In Capriolo, then, what sort of 'prison' do we see depicted? A labyrinthine place of refuge, reform, or permanent punishment? The 'gigante' is really the only character enduring enforced confinement, while Eulalia, Eugenio, Cara, Scarpia, and Vulpius are merely unwilling to leave their various prisons, although Cara does believe she is guilty of some past misdemeanour that has led to her enclosure in the hellish - or heavenly - hotel (she cannot be sure which, if either). ${ }^{28}$ Capriolo's places, like a labyrinth, are closed structures, linked not only with attraction, but also with permanence, death, and 'life'. They may represent the 'mind', or 'psyche' of the individual, revealing a sense of alienation, but also an ensuing 
security in self-knowledge or self-perpetuation (the personality, unlike the body, can live on). They are prisons, then, as viewed externally, but not felt as such by their inmates; they represent more the Pirandellian isolation within the self.

\section{Labyrinth as metaphor}

Eulalia achieves fame. Yet she only lives for the few hours spent on stage 'quando alla luce delle fiaccole rimaneva irretita dal miraggio che lei stessa creava, e si smarriva nel labirinto delle sue finzioni, come in una patria sconosciuta' (GE, p. 27). The main significance of the image of the labyrinth here is to suggest that Eulalia - habitually losing herself ${ }^{29}$ in the labyrinth of many fictions, illusions, masks - can enter, through empathy, into other personalities (the 'patria sconosciuta') while still remaining herself. In other words, she is 'others' entirely on her terms, and they cannot make demands on her in the ways that live, separate, other human beings can. This escape from the self, in representing someone else, or something else - theatre, hotel, or prison - brings liberation, which is doubtless why she chooses the mirrored world at the end, perhaps more than for any sense of gaining freedom. The actor Vulpius's case is similar. Cara, on the other hand, wondering why she is telling her story, believes she may be no more than a fictitious character out of a book, and although the thought worries her, she sees it positively, as liberating.

In 'Lettere a Luisa', the prisoner's diary, the term occurs in the context of music. The prisoner writes arrogantly of Adele, as they play impassioned duets together, though never meet: 'si addentra, seguendo le mie orme, nei labirinti piú insidiosi della musica' (LL, p. 121). He sees her following him, as if he were a necessary guide to direct her through the most difficult parts of the music, the most dangerous labyrinths. Music, portrayed as a way of communicating deeper than words which are too limiting, appears to be a metaphor for the 'affective life' of the individual, captivating and affecting emotional states. Adele, however, unlike Dante, is not protected by her guide, who has an opposite role to that of Virgil or Beatrice, leading Adele into seduction. As she becomes totally immersed in the musical experience, she becomes impervious to any other commitment (love of husband, family concerns); she becomes, in a sense, autistic, completely bound up in her own subjectivity, the labyrinth of self which, like the singing of the Sirens, leads to destruction. The feeling remains, however, that whatever the consequences, Adele and the prisoner's path, their total immersion in the musical labyrinth, is in some way worthy or honourable, as opposed to that of the outsider husband, Eugenio.

In Il doppio regno, the labyrinth as metaphor is linked closely with death. Regarding the inevitable decay of nature, Cara notes that she has long observed 'quel teatro macabro nel quale in modo brutalmente didascalico, viene inscenato lo spettacolo del declino' (DR, p. 117). The flowers Bruno has given her from the hotel garden wither and fade, whereas the hotel is 'timeless' and so its inmates are not subject to such decay. This could almost be a reference forward to the theatre of La spettatrice, which, in Vulpius's mind, is strongly linked with death: 'molti aspetti nel cerimoniale della morte, ricordavano da vicino il teatro, o forse era vero il contrario' (LS, p. 134). There is 'una parentela, un'affinità sotterranea' between them, which Vulpius will live out. The hotel labyrinth of Il doppio regno may also represent a mental maze, confusion, searching for meaning, for identity, and a place, however sepulchral, of belonging. Cara repeatedly muses over who she is, where she has come from, and what the fragments of 'memory' which invade her mind mean. She later notes:

Vivo in una mia trama di riflessioni che avvolge interamente la realtà senza tuttavia venire a contatto con essa. La tesso con un rigore febbrile e insieme apatico [...]. 
Tesso la trama, ricopro delle sue maglie serrate quanto mi circonda, e sempre torno a disfarla per tesserne una nuova. (DR, p. 151)

Similarly, the narrator of 'La grande Eulalia' sees life as a tapestry made up of a network of generations. She refers to the pattern of getting a husband, having children, seeing them marry and have children, and then lying next to them all in the cemetery, and states that she does not believe that this is the way to spend one's life between the beginning and the end, 'tessendo una maglia nella rete delle generazioni' (GE, p. 9). Neither is that of the travelling troupe, living and dying a thousand lives. She seems to feel there is a better way, rather than being a dismal speck in the immense span of time, and this is perhaps what Cara, more than any of the protagonists, is to find.

The image of the net or network - objects linked powerfully together - is connected with that of the labyrinth. It too attracts and traps, unwilling to release its prisoners. We see this, for example, in Vissi d'amore: 'È sconcertante il potere degli oggetti di intrecciare legami l'uno con l'altro sino a formare una rete nella quale facilmente si rimane impigliati' (VA, p. 23). The voices of the singers on stage at the opera are entwined 'in un groviglio sempre piú inestricabile' (VA, p. 40), and Scarpia even comes to feel pity for his prisoners: 'Anche quegli infelici si dibattevano invano nella rete che si stringeva a poco a poco intorno a loro, imprigionandoli sempre piú saldamente' (VA, p. 86). They will not manage to escape (there is no 'maglia rotta' to find), and neither will Scarpia. The verb 'irretire' is used to describe both Eulalia on stage, as we have seen ('irretita dal miraggio che lei stessa creava', GE, p. 27), and Vulpius in his theatre: inside, he is completely caught up in the magic of acting until he comes out into the fresh air, when 'riacquistò una certa coscienza di sé e l'incantamento nel quale era irretito si allentò' (LS, p. 126). The metaphorical treatment of the labyrinth, interesting from a linguistic point of view, when considered together with the various representations and reflections of the maze, takes on an even deeper significance. There is no escaping the labyrinth. We are trapped externally and internally, through experience and the telling of it.

Indeed, the act of narration itself is seen as labyrinthine in Capriolo's work, resulting in the sense of disorientation already referred to. In La spettatrice, for example, we find the narrator openly choosing which particular event or events to narrate:

Anche quella che mi accingo a narrare è soltanto una possibile storia di Vulpius, capace di render conto dei pochi elementi certi di cui disponiamo. Che sia poi la sua storia vera, o almeno la piú verosimile, non mi sentirei di affermarlo. (LS, p. 7)

Although the narrator of 'La grande Eulalia', begins her tale: 'Vi racconterò ogni cosa esattamente come si svolse' (GE, p. 7), she closes with the idea that since so much time has elapsed, all that will remain for visitors to the castle is: 'un'immagine vaga, impossibile da precisare, una storia confusa, udita tanti anni prima, chissà dove, chissà da chi' (GE, p. 42). In Capriolo's short story, 'Il dio narrante', the narrator states: 'Innanzitutto, dovrei decidere chi sono'; one of the possibilities is 'un dio dallo sguardo appannato, cui le vicende delle proprie creature si mostrano solo da lontano e in maniera confusa. ${ }^{30}$ He confuses past and present, and instants and eternity are one and the same for him. He observes events simultaneously, but obviously cannot relate them simultaneously, and so his narrative (perhaps like any narrative) is not always coherent. In fact, we are told: 'Il dio [...] come tutti gli dei è un pessimo narratore,' and that 'solo le provvidenziali lacune della memoria, la miopia dello sguardo, lo salvano dal precipitare nello sconfinato abisso della noia'. ${ }^{31}$ He can escape 'noia', however, unlike the all-knowing gods in Pavese's Dialoghi con Leucò who are utterly bored with their existence because they have no emotions and no imagination, only truth, reality, 
and ratiocination, and who envy mankind because it is able constantly to 'create' new realities (that is, illusions) which keep life interesting, varied, always changing, always new. ${ }^{32}$ 'Il dio narrante', with his clouded vision, records events but does not interfere in the affairs of the world; unlike Capriolo's main protagonists, or narrators, 'lui [...] si limita a osservare, dall'alto, con sguardo offuscato. ${ }^{33} \mathrm{He}$, not least because he is a god, will survive, he will not be drawn into the abyss.

The labyrinth, then, a dark realm of interlinked passages, physical or reflected, is there to attract as a complex puzzle, but it creates fear, uncertainty, insecurity, even danger. Yet even more than representing a threat to Capriolo's maze-treaders, it is a place (actual or illusory) of enquiry, a place of discovery, indeed of self-discovery. While there is a strong link in Capriolo's fiction between the place and death, a spiralling down towards death, we can also see the labyrinth as a metaphor for life, the ineluctable life of the self, as opposed to that so marked, perverted, and diverted by life in society.

How does one proceed inside a labyrinth? How does one tread the labyrinth of life? We tend to think of the labyrinth as endless passageways, but it is additionally a complex series of crossroads in which we are continually called upon to make choices, searching either for the route to the centre or the way out, the way forward or an escape from the present, the path to self-knowledge or a diversion into illusion. Lost and searching, the experience can resemble a dream, an anxiety dream in which one experiences things through a bewildering haze. Entering a labyrinth one relinquishes control and liberty, albeit temporarily, one is suspended in a struggle between will (or wilfulness) and instinct. And yet we make choices often on the basis of no knowledge at all, so that in reality 'freedom of choice' and 'pure chance' coincide totally. Thus the 'route' we create comes out of chance and irrationality, and so it is (Capriolo would seem to be saying) with life.

The assistance of a guide, however, may help one follow the right path of labyrinthine physical reality, in the same way as psychoanalysis may help to unravel the passages of tortuous psychic reality. Yet one cannot take for granted the fact that the guide will succeed (and what constitutes success anyway?). Are Capriolo's protagonists given any assistance to allow them to survive in their worlds? Is Guido, perhaps, a 'failed' guide for Cara? Certainly, any relationship into which the protagonists enter leads neither to serenity and peace, nor to a felicitous escape. Capriolo has stated that she does not believe that love is an element which can help one escape from the 'labyrinth of life', although love can help one understand its mysteries. ${ }^{34}$ In the novels, this process, the acting out of the obsession of the protagonist, his or her concentration on the search for love, beauty, or perfection, leads to total isolation from the 'real' world, the world of ordinary people, to a withdrawal into the self, and, in the majority of the stories, to death, although this death does not necessarily arise out of despair, but sometimes occurs almost as a fulfilment of the search. We see despair, or apparent despair, in the short stories 'La grande Eulalia' and 'Il gigante'. But there is fulfilment in the novels Vissi d'amore, La spettatrice, and especially in Il doppio regno (through death, eternal confinement, or salvation). Indeed, in this latter case, it would seem that the more Cara becomes confused, and the further she drifts from her separate reality, the more she finds her place in the hotel, in a sort of Jungian 'collective unconscious', and the more she discovers the whole, the 'self'.

The existence of a labyrinth naturally leads to considerations of a creator, a Daedalus, or god, and his possible purposes in constructing it. From what we see in Capriolo's novels, it would seem that any creator is trying to draw the created towards a total identification with place, to a state of undifferentiation, perhaps to a pre-natal or post-death state. Capriolo's 
interest in the labyrinth, then, focuses on its dual nature, as both art and confusion, but especially on its characteristic as a deathly, cut-off place. The protagonists appear compelled to follow either the tortuous and torturous path of the multicursal maze ('La grande Eulalia', Il doppio regno, and to a lesser degree Vissi d'amore), or the 'cammino obbligato' of a more unicursal model which has physically been laid out for them ('Il gigante', La spettatrice). In the former type the individual has to select the path, using or abusing 'free' will, whilst in the latter he or she does not become lost but may still feel disoriented. ${ }^{35}$ The characters can be viewed as strong, not deviating from their 'chosen' paths (or those chosen for them), or as weak in that they oppose no resistance to this pull to surrender their rationality. It is certainly a compulsion, an obsession which is stronger than the pull of life. Vulpius, for example, appears to have no choice, no will, no freedom to diverge from the path which has been ordained for him, as the narrator explicitly claims. It is clear, we read, that 'tale cammino non sia una linea retta [...] ma un cerchio dove tutto, prima o poi, è destinato a tornare' (LS, p. 165). But would the protagonists, in fact, have wanted to act differently? Scarpia, foreseeing his own end, voices this apparent dilemma:

A volte mi domando se non avrei potuto evitare tutto ciò, e gli avvenimenti che mi hanno condotto a questo punto mi appaiono come una serie di bivi a ciascuno dei quali ho imboccato risolutamente la strada sbagliata. Eppure ogni alternativa avrebbe implicato una rinuncia il cui solo pensiero mi è intollerabile, un asserragliarmi entro gli angusti confini della mia esistenza. (VA, p. 114, my emphases)

The protagonists cannot conceive of any other existence, any other direction. The abandonment of so-called rationality, and a yielding to the instinctive self, or to the obsession driving them, seems to lead right to the centre of the maze, following Montale's 'Se procedi t’imbatti | tu forse nel fantasma che ti salva'. ${ }^{36}$ I return to my opening quotation:

Nessun prezzo è troppo alto per la verità, anche se vado sempre piú convincendomi che la salvezza stia nell'errore, che il labirinto della vita si percorra piú agevolmente con sguardo offuscato. Vedere significa vedere l'abisso, da cui non è possibile tornare poi a distogliere gli occhi. (Vissi d'amore, pp. 114-15)

The quotation continues: 'Sapere significa sapersi consegnati all'annientamento'. Although there is ambiguity, the interpretation I feel most appropriate is the following: salvation may lie in taking the wrong path, in not seeing, one may need to live 'con sguardo offuscato', like 'il dio narrante', in order to survive, as Scarpia says. There seems to be no other way, if one wants to proceed through 'il labirinto della vita' securely and sedately like the majority.

Yet Scarpia and the other inhabitants of the labyrinthine spaces are not capable of living in this way. They do not aim to live 'agevolmente', they do not or cannot compromise in their search for truth, or the 'sbaglio di Natura' of 'I limoni', whatever the price. Their way may be seen as 'errore' in the eyes of the world, but all the protagonists see themselves as quite detached from and often superior to the rest of humanity. One interpretation of the lives we see depicted may be the struggle of human individuality against the natural (process of) being - a struggle ultimately doomed to failure, when in death one is again subsumed into the eternal cycle of Nature's physicality, which is essentially a Rousseauistic view of harmony with nature. Furthermore, perhaps truth can only be 'seen' when one is blind, like Tiresias, since vision of the external world distracts and distorts. Without clear sight of the world, one may gaze more easily inward, towards the centre, one descends (like Orpheus, and certain medieval mystics) into the abyss in search of wholeness. For Cara, this means reaching a 
point of total flatness, an existence where there is no conflict, no strife, no feelings, no language, no desire, because everything is sounded, measured, known, and accepted, as it is for the gods in Dialoghi con Leucò. Capriolo's protagonists are thus drawn irrevocably towards the dark abyss, perhaps Montale's 'punto morto del mondo', they thirst after meaning, seeking to be saved from a life of mediocrity, and do not depart from the path that they have chosen, refusing 'salvation' in the sense of saving their lives. Like Daedalus's son Icarus, they are unable to steer a middle course, and their inward-looking obstinacy leads to their 'annientamento', their 'end'. As Pavese said, 'L'unico modo di sfuggire all'abisso è di guardarlo e misurarlo e sondarlo e discendervi. ${ }^{37}$

Capriolo portrays the labyrinth in her stories as the fearful path to truth and to selfknowledge, and in her protagonists we see a definite pull towards remaining closed in this state, towards a permanent relinquishing of liberty, only to find it through seeking, or creating, the self. Yet at the end (or centre) of the search, it would seem that they are devoured by the monster in the maze - perhaps the self? - they finally recognize.

\section{NOTES}

\footnotetext{
${ }^{1}$ Vissi d'amore (Milan: Bompiani, 1992), pp. 114-15, my emphases; hereafter VA in the text.

${ }^{2}$ Gillian Ania, “"Un altro mondo”: Interview with Paola Capriolo', The Italianist, 18, (1998), 305-41, p. 329.

${ }^{3}$ Sharon Wood, Italian Women's Writing 1860-1994 (London: The Athlone Press, 1995), pp. 257, 272.
}

${ }^{4}$ It is not easy to place Capriolo in a literary tradition. While displaying many qualities of contemporary narrative, she is also firmly rooted in an earlier twentieth-century European tradition. See Gillian Ania, 'At Capriolo's Hotel: Heaven, Hell, and Otherworlds in Il doppio regno', Italian Studies, LIV (1999), 132-156, pp. 132-33.

${ }^{5}$ Penelope Reed Doob, The Idea of the Labyrinth from Classical Antiquity through the Middle Ages (Ithaca and London: Cornell University Press, 1990), pp. 3-5, and Chapter 2 (pp. 39-63). The text includes a very stimulating exploration of the theoretical aspect of the labyrinth.

${ }^{6}$ Doob, p. 18.

${ }^{7}$ Alessandro Cassinis, 'Il mondo finisce in un albergo', Il Secolo, 15 April 1991.

${ }^{8}$ Ben Stoltzfus, Alain Robbe-Grillet: The Body of the Text (London and Toronto: Associated University Presses, 1985), p. 42.

${ }^{9}$ The city of Alexandria in Lawrence Durrell's The Alexandria Quartet (London: Faber and Faber, 1962), and his novel The Dark Labyrinth (London: Faber and Faber, 1991); Giorgio Caproni's short story 'Il labirinto' in the collection Il labirinto (Milan: Garzanti, 1992), 63-95.

${ }^{10}$ Calvino: Le città invisibili (Turin: Einaudi, 1972); Il castello dei destini incrociati (Turin: Einaudi, 1973); Se una notte d'inverno un viaggiatore (Turin: Einaudi, 1979); Jorge Luis Borges's collection of short stories Labyrinths (London: Penguin, 1964).

${ }^{11}$ See Ania, 'Un altro mondo', p. 317.

12 'Un altro mondo', p. 317.

13 'La grande Eulalia' (hereafter GE in the text), first of four short stories in the collection La grande Eulalia (Milan: Feltrinelli, 1988), p. 16.

${ }^{14}$ La spettatrice (Milan: Bompiani, 1995), p. 100; hereafter LS in the text.

${ }^{15}$ See below, and also Ania, 'At Capriolo's hotel', pp. 140-41.

${ }^{16}$ Il doppio regno (Milan: Bompiani, 1991), p. 22; hereafter DR in the text. 'Vi erano sale raccolte come petali intorno ad anticamere esagonali, altre disposte a grappoli, in modo che la prima immettesse in due, queste in quattro, e cosí via [...]; vi erano corridoi senza porte che terminavano all'improvviso davanti a un muro, oppure descrivevano una "u" e riconducevano al punto dal quale 
erano partiti' (p. 28). See also Il doppio regno, p. 76, and 'At Capriolo's hotel', p. 134.

${ }^{17}$ Stoltzfus, p. 118.

${ }^{18}$ Eugenio Montale, Tutte le poesie (Milan: Mondadori, 1984), pp. 11-12.

${ }^{19}$ Cara's diary contains repeated references to 'verità', 'veridicità', 'la verità dell'albergo', eg. Il doppio regno, pp. 10, 66, 124, 152, 166. Further connections will be explored in my conclusions.

${ }^{20}$ Montale, p. 7. The term 'maglia' occurs in Il doppio regno (p. 151) and 'La grande Eulalia' (p. 9). See below.

21 'And therein lies the whole of man's plight. Human time does not turn in a circle: it runs ahead in a straight line. That is why man cannot be happy: happiness is the longing for repetition', Milan Kundera, The Unbearable Lightness of Being (London \& Boston: Faber and Faber, 1984), p. 298.

${ }^{22}$ See Il doppio regno, p. 65, where Cara records a poem she believes she has composed, and analyses it: 'A noi prescrisse | il fato illacrimata sepoltura', really a quotation from a sonnet by Foscolo: 'Né più mai toccherò le sacre sponde', in Odi e sonetti (Milan: Fabbri, 1968, 1969), p. 44.

${ }^{23}$ Calvino, Se una notte d'inverno un viaggiatore, p. 162.

24 'Lettere a Luisa' (hereafter LL in the text), from La grande Eulalia, p. 113.

25 'Il gigante' (hereafter IG in the text), from La grande Eulalia, p. 78.

${ }^{26}$ The same thoughts are true of the occupants of the hotel of Il doppio regno, eg. pp. 27-30, and of the theatre of La spettatrice, eg. pp. 8, 163, 167.

${ }^{27}$ See 'Un altro mondo', sections on 'Lo sguardo' and 'Lo specchio'. Capriolo comments: 'I miei personaggi tendono [...] ad identificarsi con una maschera, cioè a fissarsi in una posa, perché poi tendono sempre a ripetere lo stesso gesto, e questo rende la loro essenza in un certo senso teatrale' (p. 323). 'Ne Il doppio regno l'assenza di specchi è un segno della non sussistenza dell'io in quel luogo' (p. 328). 'C'è sempre [la] necessità di trovare una conferma di sé nella maschera, perché in fondo anche lo specchio è un caso di maschera; e poi è un caso anche di labirinto, se vogliamo, perché c'è questo continuo rimando... [delle immagini]. Poi, di solito lo specchio è moltiplicazione di specchi, come nel caso de "La grande Eulalia"; lo specchio è anche un punto in cui si congiungono, diciamo, la realtà e la finzione' (p. 329).

${ }^{28}$ See 'At Capriolo's Hotel' for a full discussion of this question.

${ }^{29}$ We may note once more the Dantean term, 'smarrirsi', as previously ('lo sguardo della ragazza si smarriva', GE, p. 17); it recurs in Il doppio regno, pp. 24, 28, 44.

${ }^{30}$ In Italian Women Writing, ed. Sharon Wood (Manchester: Manchester University Press, 1993), 12731, p. 127 (my emphasis). 'Il dio narrante' was first published in the review Leggere, August 1989, and subsequently in Italiana. Antologia dei nuovi narratori (Milan: Mondadori, 1991), 157-63. The term 'appannato' (with its collocates) is also a favourite poetic image of Caproni's, showing a clouding of vision. See the 'Stanze della funicolare' in Poesie 1932-1986 (Milan: Garzanti, 1989), 141-48, where we may note, for example: 'i nebbiosi bicchieri' (pp. 141, 148), 'i finestrini umidi' (p. 143), 'si vela | il vetro' (p. 144), ‘una nebbia l'appanna' (p. 148).

${ }^{31}$ Italian Women Writing, pp. 128, 129 (my emphases).

${ }^{32}$ The goddess Bia agrees with Cratos that men are wretched: 'Sono poveri vermi ma tutto fra loro è imprevisto e scoperta'. Cesare Pavese, Dialoghi con Leucò (Turin: Einaudi, 1965) 'Gli uomini', p. 165. See also Doug Thompson, Cesare Pavese: a study of the major novels and poems (Cambridge: Cambridge University Press, 1982), pp. 125-31.

${ }^{33}$ Italian Women Writing, pp. 129-30 (my emphasis).

${ }^{34}$ Daniele Marinoni, 'Vissi d'amore, l'ultimo romanzo di Paola Capriolo alla ricerca del senso della vita' in Il mattino di Padova, October 1993.

${ }^{35}$ See Doob, pp. 46-51, and Il doppio regno, pp. 17-18, 98. Walter of Il nocchiero (Milan: Feltrinelli, 1989 ) is also a treader of the 'cammino obbligato' (see pp. 134-35).

${ }^{36}$ Montale, 'In limine’, p. 7.

${ }^{37} 24$ April, 1936, Il mestiere di vivere 1935-1950 (Torino: Einaudi, 1990), p. 36. 